序

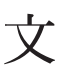

第 29 回臨床内分泌代謝 Update を令和元年 11 月 29 日(金)、30 日(土)の両日に高知市文化プ ラザかるぽーとにて開催させて頂きました。皆様のご協力のお陰をもちまして、地方都市にもか かわらず 1,800 名以上の総参加者と、一般演題と指定演題を併せ 600 題近くのご発表を賜りまし た。ご来場頂きました皆様、学会運営にご尽力くださいましたプログラム委員の先生方、査読委 員の先生方、優秀ポスター賞選考委員の先生方、講演や座長の労をお執りくださいました先生方 に、心よりお礼申し上げます。

今回の学会は、多様化する全国の内分泌学会員のニーズに応えるべく、「ココが知りたい！ホ ルモンと代謝」というテーマを掲げつつ、Update, Meet the Expert (MTE)、ABC、Clinical Case Discussion (CCD)、およびテクニカルセミナー（TC）という5つのシリーズで構成し、それぞれ エキスパートの先生方に、文字通り「ココが知りたい」ポイントを絞ったご講演を頂きました。 会場が手狭で入場困難なセッションがございましたこと、種々の運営面での不手際など、多々ご 迷惑をお脚け致しましたことを、心よりお詫び申し上げます。一方で、学会場での議論が参加者 にとって有益なものとなり、手作りの「おもてなし懇親会」が多くの方々の交流の場になりまし たとすれば、主催者としてこの上もない喜びです。

本プロシーディングでは、指定演題を含む全ての演題の中から、紙面の関係で各分野より選ば れたご発表内容が揭載されております。執筆をご快諾頂きました諸先生方に、この場をお借りし て心よりお礼申し上げます。最後に、内分泌代謝学の益々の興隆と日本内分泌学会の更なる発展 を祈念しつつ、お礼のご挨拶とさせて頂きます。

第 29 回臨床内分泌代謝 Update

会長 岩 㠃 泰 正 


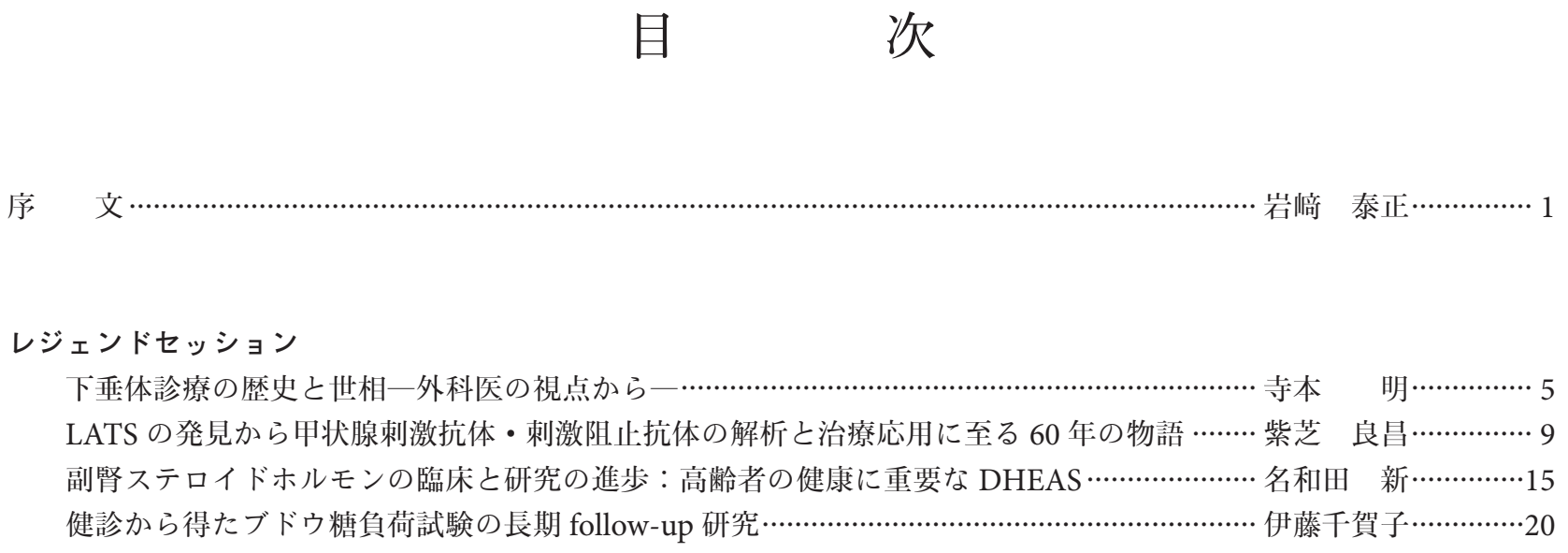

\section{JES We Can 企画}

米国における臨床内分泌代謝診療の現状………………………………………………………………荒木 貴子……………25

私の歩いた一筋の道 一糖尿病と妊娠の分野を開拓- ……………………………………………. 大森 安恵……………28

酸化障害と抗酸化防御機構……………………………………………………………………………………... 野口 範子……………32

外国人患者の受け入れと対応について ……………………………………………………………南欲がり …………36

\section{Clinical Case Discussion}

1 型 DM 感受性遺伝子を有した L-asparaginase 誘発糖尿病の一例………………………………矢藤 ＼cjkstart繁…………4 40

アミオダロンの複雑な抗甲状腺作用が出現した高齢者の 1 例…………………………………島田＼cjkstart恭輔 …………4

多発性骨㕼腫治療中に ACTH 単独欠損症と破壊性甲状腺炎を呈した 1 例 ………………………加地真理子……………45

炭酸リチウムによって甲状腺クリーゼを来した 1 例 ………………………………………………太因 充版…………4 48

病勢進行に Lenvatinib の再増量が有用であった甲状腺乳頭癌の 1 例………………………………伊澤正一郎…………51

低ゴナドトロピン性性腺機能低下症を呈した Klinefelter 症候群の 1 例……………………………稲垣 早織…………...55

減量後興味深い機能改善を認めたプラダーウイリー症候群の 1 例…………………………………藤田 寛子…………...59

腎移植後に顕在化した原発性アルドステロン症………………………………………………………金本 巨哲……………6

両側副腎摘出後も巨大結腸症の改善が得られない MEN2B の 1 例 …………………………………名部 新…………6. 67

血清 ALP 157IU/L から低ホスファターゼ症小児型を疑った 1 例…………………………………原田 大輔……………71

酵素補充療法を導入した低ホスファターゼ症成人 2 症例の検討………………………………………中野由佳子……………75

甲状腺腫瘍との鑑別が困難であった副甲状腺癌の一例…………………………………………….. 大竹 宏輝…………78

下垂体生検で診断し得なかった中枢神経 Langerhans 細胞組織球症………………………………辰島＼cjkstart啓太…………81

エルドハイム・チェスター病に中枢性尿崩症を合併した一例……………………………………… 久永 香織…………... 84

\section{優秀ポスター賞受賞演題}

先端巨大症の治療による頭蓋骨の変化についての検討 ……………………………………………伯田 琢郎…………. 88

新規 FGFR1 変異を伴う低ゴナドトロピン性性線機能低下症の 1 例………………………………… 橿尾＼cjkstart岳………….92

経ロブドウ糖・TRH 負荷による先端巨大症の個別化医療の可能性 ……………………………向井 康祐 …………95

カタラーゼ活性の低下による HbA1c 偽高值を呈した 5 例の検討 ……………………………………家＼cjkstart淳……………98 


\section{推薦一般演題}

診断・治療に苦慮した complete empty sella 合併 Cushing 病の一例…………………………… 大川 雄太…………102

高用量デキサメタゾン抵抗性サブクリニカルクッシング病 in vitro での検証 …………………

本邦に打ける 21 水酸化酵素欠損症の予後調查 …………………………………………………………棚橋 祐典………..... 107

褐色細胞腫に打ける臨床的悪性度の予測因子探索を目指した遺伝学的解析…………………… 小笠原辰樹…………111

The Effects of CAPTEM on a Corticotroph Pituitary Carcinoma …………………………………… 館野 妙…………115

8 年間 metyrapone 投与後に切除し得た ACTH 産生肺カルチノイドの 1 例 ………………………門野＼cjkstart至…………119

アナフィラキシーとして救急搬送された褐色細胞腫クリーゼの一例 ……………………………. 大原 恵未…………123

内分泌学的検查で陽性を呈した霬胞性褐色細胞腫の 1 例 ……………………………………….... 小川 雅史…………127

前立腺小細胞癌によると考えられた異所性 ACTH 産生腫瘍の 1 例 ……………………………… 大高 泰幸…………131

ACTH 産生を伴う原発不明神経内分泌腫瘍肝転移に対する集学的治療…………………………北島 浩平…………134

Carboplatin (CBDCA) + Etoposido (VP-16) 療法が著効した原発臟器不明の神経内分泌がん (NEC)の 1 例…長谷川千穗…………137

ラトケ需胞に打ける保存的観察群と手術群の後方視的臨床検討……………………………………立花＼cjkstart修……….... 141

ラトケ霊胞を伴う心因性多飲の 2 例………………………………………………………………………米田＼cjkstart麻里…………144

総合診受診後に中枢性副腎皮質機能低下症の診断に至った患者検討……………………………… 山上 啓子…………147

部分型脂肪萎縮症合併 $\mathrm{A}$ 型インスリン抵抗症 2 例の臨床的特徵の検討………………………簏西 真規…………150

65 歳以上の成人成長ホルモン分泌不全症患者への成長ホルモン補充効果の検討 ………………羽田幸里香…………154

非機能性下垂体腺腫再手術後に下垂体膿瘍を呈した 1 症例…………………………………………花田＼cjkstart朋子…………158

SOX2 遺伝子異常による続発性性腺機能低下症の 1 例………………………………………………原＼cjkstart知之………...161

インフルエンザ後に中枢性尿崩症を発症した一例……………………………………………….... 橋本真紀子………..... 164

橋本病を合併したダウン症患者の臨床的特徵に関する検討…………………………………………. .岐真智子…………168

甲状腺クリーゼを契機に発見された Struma ovarii 肝転移の一例……………………………………舟橋夕貴子…………171

倦急感・体重減少を主訴に受診した多腺性自己免疫症候群 3B 型の 1 例………………………… 大坂 直也…………174

IgM の非特異反応により一過性の FT3・FT4 偽高值を呈した 1 例 ………………………………酒井 裕幸…………177

原発性甲状腺機能低下症に MRHE を合併し低 $\mathrm{Na}$ 血症を呈した一例…………………………… 木村 圭汰…………180

サイログロブリン $(\mathrm{Tg})$ 遺伝子異常症の血清 $\mathrm{Tg}$ /甲状腺体積比……………………………………笠原 俊彦…………182

グルココルチコイド奏功性アルドステロン症の診断に至った若年発症高血圧の一例…………星野 良朋…………185

エストラジオール製剤内服中による高コルチゾール血症と CBG への影響………………………萩原＼cjkstart莉恵…………18 